\title{
The political effects of emergency frames in sustainability
}

\author{
James Patterson ${ }^{1 凹}$, Carina Wyborn $\oplus^{2}$, Linda Westman $\oplus^{3}$, Marie Claire Brisbois ${ }^{4}$, \\ Manjana Milkoreit ${ }^{5}$ and Dhanasree Jayaram ${ }^{6}$
}

Emergency frames are mobilized in contemporary sustainability debates, both in response to specific events and strategically. The strategic deployment of emergency frames by proponents of sustainability action aims to stimulate collective action on issues for which it is lacking. But this is contentious due to a range of possible effects. We critically review interdisciplinary social science literature to examine the political effects of emergency frames in sustainability and develop a typology of five key dimensions of variation. This pinpoints practical areas for evaluating the utility of emergency frames and builds a shared vocabulary for analysis and decision-making.

T he notion of emergency has become prominent in contemporary sustainability science and politics. Sustainability issues, especially climate change and biodiversity loss, are increasingly declared as society-wide emergencies by scientists, civil society groups, cities, national governments and international organizations in an attempt to focus attention and accelerate action. Only five years after the first climate emergency declaration in 2016, almost 2,000 such declarations have been issued (https:// climateemergencydeclaration.org). At the same time, acute and unprecedented climate change-related impacts (for example, wildfires, droughts, floods) are occurring with increasing frequency and magnitude, creating sharply felt emergencies in specific locations, and anxiety about the futures they portend. An emergency frame is a sense-making lens that conveys the meaning that a given set of circumstances constitutes an emergency. However, the consequences of using emergency frames in sustainability governance are complex, and, so far, not well understood. Moreover, the strategic deployment of emergency frames is contentious. While the urgency and irreversibility of unfolding global environmental changes are highlighted as justification, scholars disagree about the implications and merits of emergency frames for advancing collective action, and sometimes even strongly caution against it. Making sense of this contradictory picture requires a critical synthesis of the diverse possible effects of emergency frames to inform effective and politically astute responses.

The political effects of emergency frames may vary across different times, places and issue domains, and depending on who mobilizes this framing. For example, emergency frames may convey the urgency necessary to avoid further destruction of the environment and promote positive action ${ }^{1}$, thereby opening up new political possibilities for consensual sustainability action. But emergency frames may also polarize debates ${ }^{2}$, lead to public fatigue over time, trigger political defensiveness or even enable power grabs. Different scholarly disciplines and fields identify various fragmented aspects of this picture, creating ambiguity and conflicting claims about the normative merit of emergency frames and, worryingly, their actual empirical effects. Therefore, whether emergency frames are conducive or counterproductive to mobilizing sustainability action-and ultimately societal transformations-is not clear. Despite growing attention to the emergence of emergency frames, there is a lack of systematic understanding of their effects in sustainability governance, as well as their variation within and across contexts. Furthermore, experiences under the coronavirus disease 2019 (COVID-19) pandemic give new impetus for understanding the range of effects that might arise under emergency involving governmental, social and even military actions.

This Review synthesizes interdisciplinary insights concerning the political effects of emergency frames across diverse but fragmented disciplines. This material draws from: political science (22.1\%), sustainability science $(16.8 \%)$, policy studies $(13.3 \%)$, sociology (12.4\%), human geography (10.6\%), social psychology $(8.8 \%)$ and others (including law and human rights, science and technology studies, science communication; 15.9\%) (Supplementary Note 1). The focus is on emergency frames in the field of environmental sustainability, but also draws on insights from other substantive fields (for example, disaster/crisis, social justice, security studies, COVID-19) where this is particularly relevant for understanding the political effects of emergency frames in sustainability. This enables an interdisciplinary review of the specific issue of emergency in sustainability to uncover diverse insights on this topic and provide a foundation for future work.

The methodology involved: (1) an exploratory dialogue with a global interdisciplinary group of approximately 50 social scientists at the 2020 Virtual Forum on Earth System Governance (16 September 2020) to inductively identify key themes; (2) structured literature searches to identify relevant issues and debates; and (3) interpretive review ${ }^{3}$ among the interdisciplinary author team to identify key effects and debates. The material reviewed was evenly split between speculative work (that is, primarily conceptual and/ or opinion; $49.6 \%$ ) and empirically informed work (that is, empirical using original data $28.7 \%$ or synthesis compiling existing data $21.7 \%$; 50.4\%) (Supplementary Note 1). Our findings result in a

${ }^{1}$ Copernicus Institute of Sustainable Development, Faculty of Geosciences, Utrecht University, Utrecht, The Netherlands. ${ }^{2}$ Institute for Water Futures, Fenner School of Environment and Society, College of Science, Australian National University, Canberra, Australian Capital Territory, Australia. ${ }^{3}$ The Urban Institute, University of Sheffield, Sheffield, UK. ${ }^{4}$ Science Policy Research Unit (SPRU), University of Sussex, Sussex, UK. ${ }^{5}$ Department of Sociology and Human Geography, University of Oslo, Oslo, Norway. ${ }^{6}$ Department of Geopolitics and International Relations, Manipal Academy of Higher Education, Manipal, India. 凶e-mail: j.j.patterson@uu.nl 
typology comprising five dimensions of variation in the political effects of emergency frames: (1) engagement among mass publics; (2) empowerment or disempowerment of social actors; (3) shifts in formal political authority; (4) reshaping of discourse; and (5) impacts on institutions. The overall implication is that sustainability scholars, policymakers and civil society should not be too quick to embrace nor discard the notion of emergency, as its utility may vary across contexts (for example, in interplay with existing debates, and depending on the presence of safeguards against adverse consequences) and over time (for example, short-term versus long-term role in stimulating and reinforcing societal transformations).

\section{Emergency frames}

This section first empirically profiles the attention on emergency in current sustainability debates, and then elaborates on the notion of an emergency frame and its attributes.

Emergency in contemporary sustainability. The use of emergency frames occurs in two distinct ways in contemporary sustainability science and politics. First, emergency frames are employed in response to acute issues. Examples include the 'day zero' water crisis in Cape Town in $2018^{4}$, unprecedented wildfires in Australia in 2019-2020 , major wildfires in the Amazon (2019-2020) and the western United States (2020), and recent climate change-related disasters in India in 2018-2019, including a 'day zero' water crisis in Chennai and devastating floods in Kerala. Second, emergency frames are now being deployed as a strategic tool to mobilize attention, resources and effort to address an issue for which action is lagging. Examples include climate emergency declarations issued by scientists $^{6-8}$, social movements ${ }^{9-12}$, cities and municipalities ${ }^{13-15}$, and parliaments, and also recently declarations of a biodiversity emergency $^{1,16}$. The United Nations Environment Programme has been labelling both climate change and biodiversity as emergencies on its websites since 2019, and issued a report to "tackle the climate, biodiversity and pollution emergencies" in 2021 $1^{17}$. Furthermore, in a state of the planet address in December 2020, United Nations Secretary-General António Guterres declared a climate and biodiversity emergency, normalizing these frames within the multilateral governance arena. Illustrative examples of these two ways of employing emergency frames are given in Table 1.

Climate emergency frames are becoming especially prominent, as reflected in the results of a survey conducted by the United Nations Development Programme in 2020, which found that $64 \%$ of people around the world thought of climate change as an emergency ${ }^{18}$. The diffusion of emergency frames has multiple drivers, both scientific (for example, the Intergovernmental Panel on Climate Change (IPCC)'s Special Report on Global Warming of $1.5^{\circ} \mathrm{C}$ in $2018^{2,6}$ ) and socio-political (for example, social mobilization by climate movements). Importantly, emergency frames have a history in domains beyond sustainability, most obviously in relation to the COVID19 pandemic $^{19,20}$, but also in disaster management ${ }^{21-24}$, security ${ }^{25,26}$, migration $^{27}$ and even colonialism ${ }^{28,29}$. The politics of emergency frames in sustainability is, therefore, unavoidably entangled with broader issues and debates.

Conceptualizing emergency frames. A 'frame' refers to an interpretive lens, comprising symbols, categorizations and stories for delimiting and making sense of an issue by providing comprehension and suggesting responses ${ }^{30,31}$. The concept of frames emerged within multiple disciplines, including language studies, sociology, psychology and political science ${ }^{32}$. A frame conveys the essence of a controversy ${ }^{33}$, shaping how controversies are dealt with by highlighting certain features of an issue but obscuring others ${ }^{34}$. Framing influences attitudes and behaviours of individuals and groups on political issues ${ }^{35}$. As such, frame competitions can arise ${ }^{22}$, which may risk capture by political elites but can also afford new opportunities to comprehend problems through challenges to dominant frames. However, any single frame can have varying effects on people, depending on, for example, their ideological affiliation ${ }^{36}$, as observed in climate policy ${ }^{37,38}$.

An emergency frame is a way of constructing a political issue as exceptional and urgent, which demands action to avoid catastrophe $e^{7,29,39}$. Frames have been found to play a key role in the politics of disasters $/$ crises $^{40}$, as various actors use frames to politicize events and assign or deflect blame $e^{41,42}$. Declarations of emergency may also enable the allocation of extraordinary powers and shifts in authority (including to unelected officials). Yet, defining what exactly constitutes an emergency is not straightforward, especially for emergencies that are more open-ended. For example, in climate emergency declarations, framing work involves 'crisification' ${ }^{2}$, invoking specific qualities of unpredictability, irreversibility, rapid change and critical juncture ${ }^{43}$, but importantly also hope ${ }^{43}$ that action can lead to better outcomes. Recently, multiple emergency frames are being bundled (for example, climate and biodiversity as interconnected emergencies $^{44}$, climate change as a public health ${ }^{8,45}$ and human rights ${ }^{46}$ emergency, links between climate change and racism $^{47}$ ).

The notion of 'emergency' emphasizes a need for action or response to an acute threat or crisis. Yet, the very notion of emergency makes subtle assumptions about normalcy in the face of such threats. For emergency-as-reaction, the typical imperative is for a return to pre-existing conditions ${ }^{43}$. In contrast, emergency-as-strategy typically assumes the untenability of the status quo, where this status quo is 'othered' to observe its pathology and choose anew. In other words, emergency-as-strategy is about creating an exception to the norm as a political intervention to make an existing situation visible in a new way. Thus, despite emergency frames being central in both situations, the politics of emergency may be very different, particularly since climate or biodiversity emergencies are open-ended and without quick resolution, suggesting ongoing political struggles and complex consequences. Nonetheless, emergency-as-reaction may also have potentially far-reaching consequences, as witnessed during the COVID-19 pandemic with reconfigurations of legal authority, expanded use of militaries in domestic tasks and expanded surveillance $\mathrm{e}^{19,48,49}$.

Who is involved in defining an emergency is inherently political. This may involve networks of experts, the media, politicians and the general public. The construction of an emergency frame involves sense-making (that is, articulation and promotion of an explanatory narrative) within uncertain situations and incomplete information $^{50,51}$. From a social constructivist perspective, emergencies are not treated as objectively existing, but rather as co-constructed through shared experiences, perceptions and communications of threat and urgency ${ }^{24,52}$. Elite capture of such deliberations can, however, lead to a singular focus and reductive logic that overlooks trade-offs across diverse issues in heterogeneous societies, and also privileges centralized state responses over pluralistic responses that could ultimately be more effective $\mathrm{e}^{53-55}$. Notably for climate emergency, actors outside the mainstream (for example, youth movements and small local governments ${ }^{13,15}$ ) have played a crucial role, often closely tied to cognate demands for justice and equality. These demands have been embedded in the 'green (new) deals' currently debated in Europe ${ }^{56}$ and North America ${ }^{57}$. Clearly power plays a role in framing emergencies, but this may be more complex than simply reinforcing pre-existing asymmetries, suggesting that power should be seen within a longer-term perspective of evolving political struggle, that is, over which emergency, for whom and according to whom?

Also bound up in the notion of emergency are claims about the pace and scale of response. Emergency frames imply a need for rapid and substantive action that matches the scale of threat. For emergency-as-reaction, responses often attempt to overcome immediate danger, although doing so may require transformative 


\section{Table 1 | Illustrative empirical cases of emergency frames in sustainability}

\begin{tabular}{|c|c|c|c|}
\hline Case & Nature of emergency & Context & Key actors \\
\hline \multicolumn{4}{|l|}{ Emergency-as-reaction } \\
\hline $\begin{array}{l}\text { 'Black Summer' wildfires } \\
\text { in Australia (2019-2020) }\end{array}$ & $\begin{array}{l}\text { - Major wildfires with } \\
\text { unprecedented impact and } \\
\text { duration } \\
\text { - Formal state of emergency } \\
\text { declared several times by state } \\
\text { and territory governments } \\
\text { - Discursively linked by some to } \\
\text { climate emergency }{ }^{98}\end{array}$ & $\begin{array}{l}\text { - } 2019 \text { was the hottest and } \\
\text { driest year on record } \\
\text { - Fires now being attributed to } \\
\text { climate change } \\
\text { - Increase in public concern } \\
\text { about climate change } \text { end12 }^{111}\end{array}$ & $\begin{array}{l}\text { - Governments (state/territory, national) } \\
\text { - Rural fire service (voluntary) } \\
\text { - Australian Defence Force } \\
\text { - Public health system } \\
\text { - Communities } \\
\text { - Local businesses }\end{array}$ \\
\hline $\begin{array}{l}\text { Floods in Kerala and 'day } \\
\text { zero' drought in Chennai, } \\
\text { India (2018-2019) }\end{array}$ & $\begin{array}{l}\text { - Record floods in Kerala in } 2018 \\
\text { and severe drought in Chennai in } \\
2019 \text { placed spotlight on climate } \\
\text { impacts and risks } \\
\text { - Climate emergency invoked by } \\
\text { some actors, but also debated } \\
\text { due to other vulnerabilities } \\
\text { (for example, development, } \\
\text { regulatory, preparedness) }\end{array}$ & $\begin{array}{l}\text { - Emergency somewhat } \\
\text { normalized due to frequent } \\
\text { disasters and losses } \\
\text { - Emergency arrangements } \\
\text { evolving over time from colonial } \\
\text { origins } \\
\text { - Climate vulnerability } \\
\text { increasingly recognized } \\
\text { rhetorically but policy changes } \\
\text { typically small } \\
\text { - Governance failures (for } \\
\text { example, violations of } \\
\text { regulations }\end{array}$ & $\begin{array}{l}\text { - Governments (local, state, national) } \\
\text { - Specific agencies (for example, State Disaster } \\
\text { Management Authority) } \\
\text { - Non-governmental organizations (local and } \\
\text { international) } \\
\text { - Civil society initiatives (for example, fishermen) } \\
\text { - Private actors (for example, water providers) }\end{array}$ \\
\hline \multicolumn{4}{|l|}{ Emergency-as-strategy } \\
\hline $\begin{array}{l}\text { Climate emergency } \\
\text { declarations } \\
\text { (2016-present) }\end{array}$ & $\begin{array}{l}\text { - Climate emergency declared by } \\
\text { an increasing number of actors in } \\
\text { response to mismatch between } \\
\text { scale/pace of policy action and } \\
\text { climate risks identified by science } \\
\text { - Aim to stimulate rapid and } \\
\text { ambitious action to avoid future } \\
\text { impacts and changes }\end{array}$ & $\begin{array}{l}\text { - The concept of climate } \\
\text { emergency arose from scientific } \\
\text { calls }{ }^{7} \text { and increasing urgency } \\
\text { in international science } \\
\text { assessments (for example, } \\
\text { IPCC reports) and was taken } \\
\text { up by civil society groups (for } \\
\text { example, Fridays For Future), } \\
\text { local and national governments, } \\
\text { and international organizations }\end{array}$ & $\begin{array}{l}\text { - Scientists } \\
\text { - Governments and/or parliaments (local, national, } \\
\text { supranational) } \\
\text { - United Nations } \\
\text { - Social movements (for example, Fridays For Future, } \\
\text { Extinction Rebellion) } \\
\text { - Professional associations (for example, engineers, } \\
\text { architects) } \\
\text { - Businesses } \\
\text { - Educational bodies }\end{array}$ \\
\hline $\begin{array}{l}\text { Biodiversity emergency } \\
\text { declarations } \\
\text { ( 2019-present) }\end{array}$ & $\begin{array}{l}\text { - Biodiversity emergency } \\
\text { articulated by scientists in } \\
\text { response to accelerating rates } \\
\text { of ecosystem destruction and } \\
\text { biodiversity loss } \\
\text { - Sometimes framed as a twin } \\
\text { emergency of biodiversity and } \\
\text { climate change, drawing attention } \\
\text { to human health and well-being }\end{array}$ & $\begin{array}{l}\text { - Calls for 'emergency measures' } \\
\text { to protect individual species in } \\
\text { extreme situations have a long } \\
\text { history in conservation, including } \\
\text { contested calls to use military } \\
\text { force as 'last resort'114 } \\
\text { - Contemporary calls typically } \\
\text { do not mention these previous } \\
\text { debates, drawing instead on } \\
\text { similar rhetoric to climate } \\
\text { emergencies }\end{array}$ & $\begin{array}{l}\text { - Scientists } \\
\text { - United Nations Environment Programme and United } \\
\text { Nations Environmental Assembly } \\
\text { - National governments (Ireland) } \\
\text { - Social movements (for example, Extinction Rebellion) } \\
\text { - Professional associations (for example, architects, } \\
\text { construction) }\end{array}$ \\
\hline
\end{tabular}

action to address root causes of vulnerability ${ }^{58}$. There are also widespread examples of responses to emergency-as-reaction being used to advance the political goals of powerful incumbent actors (for example, public education reforms in New Orleans post-Hurricane Katrina $)^{59}$. For emergency-as-strategy, the deployment of emergency frames is geared towards stimulating urgency (for example, speed) and increased ambition of action in the absence of immediate danger. Thus, a key difference between emergency-as-reaction and emergency-as-strategy is that the former centres on a response to impacts that have manifestly occurred, whereas the latter strategically aims to avoid impacts in the future. These stances can become enmeshed, as shown in the cases of the Australian wildfires and water-related crises in India (Table 1) where specific crisis events came to support the strategic deployment of emergency frames, through locating the source of crises within broader narratives about climate emergency.

\section{Variation in political effects}

The political effects of emergency frames were found to vary across five key dimensions (Fig. 1): (1) engagement among mass publics, including affect, emotions and arousal, motivations, and behaviours; (2) empowerment or disempowerment of actors, including ability to accomplish tasks, influence over others and patterns of inclusion/exclusion; (3) exercise of formal political authority, including effects on rule of law, consent/legitimacy and democratic accountability; (4) reshaping of discourse, including effects on public attention, political imaginaries and embedding of new ideas (for example, transformation); and (5) impacts on institutions, including strengthening or weakening existing institutions, and new mechanisms of steering. This typology enables systematic analysis of variation in effects, both within individual cases and comparatively as illustrated in Boxes 1-3, which can support the derivation of contextually grounded policy implications. 


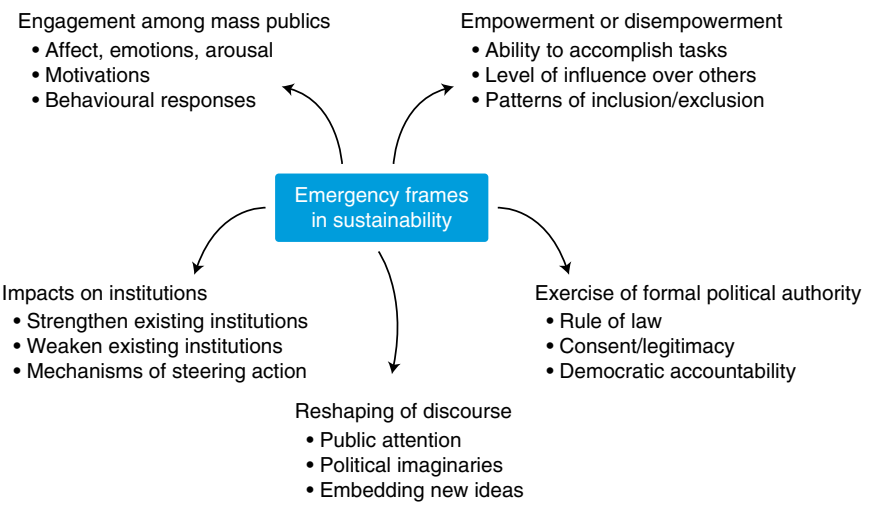

Fig. 1| Emergency frames in sustainability. The political effects of emergency frames vary across five key dimensions.

Engagement among mass publics. Emergency frames typically aim to increase the engagement of mass publics by generating attention and political activism, changing perceptions of urgency and risk, and building support for action. This can have complex psychological and cognitive consequences, involving affect (that is, state of mind and bodily experience), emotions and psychological arousal (for example, distress, excitement), which influence motivation for action. Engagement may increase or decrease, and vary for different individuals and groups.

Emergency frames can be energizing, as witnessed by the diffusion of climate emergency declarations and school student strikes, which can imbue inspiration, hope $e^{43}$ and a sense of efficacy ${ }^{60}$. But emergency frames can also be emotionally draining and create exhaustion, anxiety, guilt and fear ${ }^{2,11,61,62}$. Fear can have ambiguous and sometimes counterproductive effects on motivation to act ${ }^{63,64}$. Research on climate change and fear reveals that existential threats can "increase commitment to one's worldview, self-esteem, and relationships, and increase defence of these entities when threatened"65. In such situations, people are likely to cling to existing thoughts, values and ideology, regardless of necessary action to address the crisis. Existential fear can also trigger increased commitment to action from those already concerned about certain issues, such as protest or the pursuit of goals that outlive individuals (for example, change in legislation, new infrastructure $)^{66}$. Recently, some scholars have questioned whether concerns about fear-based messaging are overstated $^{67}$, suggesting the need to strike a balance between animating a sense of urgency and triggering denial or inaction ${ }^{2}$.

Typically, the notion of emergency is associated with a threat to survival or health, triggering heightened states of psychological arousal (for example, distress, excitement). However, arousal is a threshold property, and overwhelming this threshold closes down the capability to respond ${ }^{68}$. In cases of emergency-as-reaction, arousal is important to address an immediate threat. In cases of emergency-as-strategy, arousal will be difficult to sustain and could risk overwhelming some people with distress even while animating others. Arousal is related to the sense of urgency invoked by emergency. Yet, there is ambiguous evidence regarding the effect of time pressure on behavioural responses, including risk of inaction caused by optimism bias ${ }^{67,69}$ or increased willingness to cope with risk $^{70}$. Under COVID-19, frustrations with sustained restrictions have emerged, even where initial solidarity was present. This suggests that motivation for collective action in response to sustained crises may erode over time (although evidence here is ambiguous ${ }^{71}$ ). Mismatches between rhetoric and action could also have adverse motivational consequences for mass publics (for example, disappointment, resignation), which could undermine the potential for future public ambition-what if the measure of last resort has been exhausted without the desired effects?
The deployment of emergency frames is underpinned by an assumption that recognizing emergency will promote radical responses, including individual behaviour change, norm following and policy support. While this could occur for emergency-as-reaction where behavioural responses are temporary, scholarly literature is mixed as to whether emergency-as-strategy will have similar effects. For example, despite widespread apocalyptic language in climate communication, policy interventions rarely move beyond technocratic, incremental interventions ${ }^{72}$. Dystopic imagery appears to have limited ability to change individual actions ${ }^{64,73,74}$. Elsewhere, a 'boomerang effect' has been observed in areas such as health and anti-littering campaigns, where psychological reactance or assertions of freedom increases the behaviour that is intended to be reduced $^{75}$. Conversely, exposure to emergency frames (for example, as measured by familiarity with Greta Thunberg) may increase the propensity to engage in climate activism ${ }^{60}$. This suggests a complex range of possible consequences for engagement among mass publics, and variation among social groups (for example, based on gender and cultural worldview $)^{76}$.

Empowerment or disempowerment of actors. Empowerment or disempowerment of actors refers to shifts in power that either increase (empower) or decrease (disempower) the power of a particular actor relative to others. This centres on the 'power to' accomplish tasks, as contrasted against 'power with' (that is, cooperation) or 'power over' others (that is, domination) ${ }^{77}$. Emergency frames may have different consequences for different actors, relating to the ability to accomplish tasks, level of influence over others and patterns of inclusion/exclusion.

Empowerment/disempowerment is shaped by the type of emergency frame deployed. For example, different combinations of actors and goals are involved in the emergency-as-reaction and emergency-as-strategy cases in Table 1. Emergency-as-reaction may empower those with existing responsibility for emergency response (for example, emergency services, certain government agencies, non-governmental organizations) through the wielding of formal powers and moral authority. The pressure to 'return to normal' may disempower those seeking ambitious changes or a radical break with the past. Emergency-as-strategy may empower new actors seeking to claim authoritative status (for example, scientists) and influence other actors (for example, social movements), or create a mandate for decisive action (for example, governments/parliaments). This approach also seeks to disempower those opposing radical action (for example, certain businesses, lobbyists, politicians).

Through mobilizing climate emergency frames, new actors seek influence in climate debates. Perhaps most prominently, Fridays For Future has elevated school students as a new category of actors through claiming (moral) power of youth, undermining that of existing leaders ${ }^{10}$. Extinction Rebellion has also become prominent in some countries. These actors argue that a climate and biodiversity emergency warrants extraordinary mobilization of attention and resources ${ }^{7}$. While they have received public attention and made some political gains (for example, creation of a UK citizen's climate assembly), it is unclear whether they have mobilized necessary resources or power to create systemic political change. Furthermore, there have been struggles over empowerment. For example, in Australia, the credibility and authority of 'youth' has been challenged by actors holding formal authority (for example, the prime minister $)^{78}$.

Further insights regarding emergency-as-strategy arise in the context of racism, colonization and violence. Black Lives Matter activists deployed the idea of emergency to draw attention to the normalization of ordinary violence in the context of institutionalized racism. Here, "naming a state of emergency is to recognize and interrupt an already existing condition of existence that mixes the endemic and evental" ${ }^{43}$. The act of declaring an emergency is used 


\section{Box 1 | 'Black Summer' wildfires in Australia (2019-2020)}

In 2019-2020, Australia faced unprecedented fire conditions. Following the hottest and driest year on record, the fire season started two months early and ended with major fires across the southeast burning 24 million hectares. Thirty-three people died as a direct result of fires and an estimated 400+ more from smoke-related respiratory issues. Over 3,000 homes were destroyed with over AUS $\$ 10$ billion in financial impacts, and nearly 3 billion animals were killed or displaced. The scale and magnitude of Black Summer fires was unparalleled, triggering multiple declarations of a state of emergency. Emergency management in Australia is the remit of the states and territories, but these events placed substantial pressure on the federal government to respond. The military was called in to support evacuation and response.

The intensity of the fires ${ }^{111}$ and lack of national leadership on climate change triggered fractured political debates concerning climate policy, hazard reduction burning and the extent to which the fires were exacerbated by 'pro-environmental' policies. The fires increased concern among Australians about climate change ${ }^{112}$, and led to widespread protests and growing calls for the declaration of a climate emergency ${ }^{98}$. Government rhetoric on climate change shifted to emphasize resilience and adaptation but with limited discussion concerning mitigation ${ }^{112}$.

This case demonstrates both emergency-as-response and emergency-as-strategy. In multiple cities, people became aware of health impacts of smoke, leading to calls of a 'health emergency' under climate change ${ }^{115}$, and increasing public support for action ${ }^{112}$ (engagement). Despite its reluctance, the Australian Defence Force was used for humanitarian and disaster relief, giving the military an increased role ${ }^{81}$ (empowerment). The emergency declaration powers of the national government are likely to increase following a post-disaster inquiry that recommended such powers would assist with signalling the severity of a crisis and making actions more transparent ${ }^{5}$ (political authority). The national government sought to re-focus attention on resilience, adaptation and forest management rather than climate mitigation ${ }^{81,112}$, for example, by excluding the latter from the post-disaster inquiry. While the long-term effects are not yet known, public anger, frustration and trauma could create shifts in public discourse (discourse). The post-disaster inquiry recommended various institutional changes relating exclusively to emergency response capacity, such as new advisory bodies, and a review of the role of the defence force (institutions).

to build recognition of unendurable conditions of life that have long been ignored or denied. Indigenous studies scholars have criticized the deployment of emergency frames that rely on settler colonial social structures and deny the legacy of violence and loss experienced by Indigenous peoples ${ }^{79}$. These insights show that the potential for empowerment/disempowerment through emergency frames is contingent on broader social structures (for example, institutionalized racism, histories), but also the possibilities for society-wide action that may arise through naming long-ignored circumstances.

Relatedly, emergency frames may also resonate with longer-term patterns of inclusion/exclusion. Emergency frames demanding sweeping action by government could afford political coverage for unpopular actions and overcome veto points ${ }^{59}$. Yet, poor and/ or minority communities may lose voice if emergency frames are oriented towards quick fixes ${ }^{53}$. For example, within international development, emergency frames have been criticized for potentially undermining developing states' sovereignty and reinforcing inequalities ${ }^{80}$. This suggests tensions between emergency frames that empower certain actors while disempowering others.
Exercise of formal political authority. Exercise of formal political authority refers to instances where governments compel other actors to take action, through formal or normative authority. While this dimension partially overlaps with empowerment/disempowerment (which focuses on the relative balance in power between actors), the exercise of formal political authority relates to the use or intensification of power by a particular (core) actor: government. It thus centres on 'power over' others (for example, domination, exercise or threat of violence) $)^{77}$, relating to issues of rule of law, consent/ legitimacy and democratic accountability.

Emergency-as-reaction may bolster the political authority of governments in a particular crisis. However, this is unlikely to be straightforward as seen, for example, by the Brazilian government's recent efforts to downplay major fires in the Amazon and associated resistance to emergency action. On the other hand, the unprecedented imposition of restrictions within COVID-19 pandemic responses across many areas of social life (for example, gathering, work, travel) shows that swift and radical action is possible. Yet, over time the legitimacy of these restrictions may erode. In relation to emergency-as-strategy, governments may resist adopting climate emergency stances to avoid expectations for swift and strong action. For example, despite the unprecedented scale and impact of the Australian wildfires in 2019-2020, the national government has resisted calls for climate action (Table 1) and dismissed students declaring climate emergency (see previous section). Under conditions of emergency, such as COVID-19, governments may extend authority into new areas (for example, surveillance), which may be in tension with liberal values ${ }^{48}$. Moreover, a legitimacy gap could arise if actions in response to a declared emergency are not proportionate to the scale of the threat-a dynamic already becoming visible where these declarations have been made by governments.

Many scholars express concerns over the democratic implications of emergency frames. A frequently raised issue is threats stemming from rapid decisions that foreclose democratic deliberation, fast-track action, and remove normal checks and balances ${ }^{29,39,49}$. Some argue that this can lead to new forms of control, potentially advancing securitized or militarized responses ${ }^{81}$. Within security studies, emergency governance is associated with overcoming constraints of the rule of law. This raises questions about the use of emergency frames, particularly under extended or permanent states of emergency ${ }^{25,29}$, and where emergency tools extend into non-traditional domains ${ }^{25,26}$ such as sustainability. Scholars in the 'Copenhagen School' draw attention to the ways in which speech acts can lead to an issue being portrayed as a security threat and 'securitized', thereby permitting extraordinary measures to be taken $^{82}$. Emergency powers can enable state control over issues through means of violence, for example, to repress insurgencies or unrest. A historical perspective on states of emergency reveals the appropriation of the concept by capitalist and colonial states to repress class struggles and quell popular mobilization ${ }^{29}$. This legacy underlies many concerns regarding emergency declarations adopted as a state-led political strategy, due to tensions with liberal democratic values ${ }^{19,49}$. Nonetheless, while framing climate change as an emergency is viewed as an indicator of securitization by some ${ }^{83,84}$, others find limited evidence of this ${ }^{85}$.

Similar concerns in sustainability have arisen about whether the narrow framing of 'climate emergency' empowers a technocratic elite and undermines a plurality of goals and political creativity necessary to address justice and well-being concerns bound up in sustainability $^{53,54}$. Deploying emergency-as-strategy could normalize a pre-emptive logic that could "close down debate and legitimize otherwise unpalatable options" ${ }^{\prime 66}$. Conversely, declarations of emergency that emerge from civil society may be viewed as a democratization of governance within gridlocked political systems. A recent review of climate emergency declarations by municipalities found no tendency towards authoritarian governance. Rather, participation 


\section{Box 2 | Floods in Kerala and 'day zero' drought in Chennai,} India (2018-2019)

In 2018-2019, India experienced a series of disasters that led many actors to invoke notions of climate and water emergency. The southern state of Kerala received above-normal rainfall during the summer monsoon 2018. The 'monsoon fury' was one of the worst state disasters in almost a century, killing nearly 500 people, displacing more than a million and causing estimated economic losses of over US\$3.8 billion ${ }^{116}$. Chennai, a port city with a population of over 8 million, experienced an acute water crisis in 2019, triggering discussion of a 'day zero' declaration among city officials ${ }^{117}$. Some short-term institutional changes at different levels of governance emerged, but the disasters did not motivate long-term structural changes.

In both cases, ill-planned development (for example, infrastructure in ecologically fragile areas), violation of laws and regulations, inadequate emergency preparedness and poor natural resource management exacerbated the impacts of climate change ${ }^{118}$. For instance, in Chennai, social disparity in water access and unplanned urbanization shaped the severity of the 'day zero' crisis. Hence, governance failure is commonly blamed for disasters in India.

The dynamics giving rise to emergency frames were short-lived and quickly led to normalization-what used to be extreme was soon considered the 'new normal'. In both cases, a climate emergency was invoked, particularly by student-led groups, but other narratives gained more traction (discourse). Both emergencies highlighted the lack of preparedness of government agencies, even in providing early warning to citizens. They also revealed actors taking on new roles, such as fishermen acting as 'first responders' ${ }^{119}$ (empowerment). While these events created opportunities for greater involvement of citizen groups and civil society organizations, the response focused on technocratic solutions that reinforced existing governance gaps and social inequalities (disempowerment). Narratives have shifted as these and other disasters cumulatively encouraged scientists and authorities to recognize climate change as a potential cause for annual flooding events ${ }^{116}$. Yet, despite several changes (for example, strengthening water policy and state-level disaster management authority), emergency frames have not yet ushered in major reform. The Indian government is reluctant to adopt climate emergency declarations or net-zero emissions targets due to a paucity of technology and finance (institutions).

was shaped by the history of engagement, type of political system and role of civil society in shaping political outcomes ${ }^{85}$. Moreover, a key question for emergency frames in sustainability is whether they are expected to usher in new modes of decision-making, or simply faster decision-making using existing political authority.

Reshaping of discourse. Discourse involves broad sets of ideas and conceptual schema by which meaning is communicated, which are reproduced or transformed through social practices ${ }^{87}$. While a frame is a specific interpretive device, discourse refers to the broader landscape of ideas and practices within which specific frames are situated. An emergency frame might reinforce or conflict with a dominant discourse, or influence the relationship between competing discourses (for example, directing public attention, introducing new imaginaries, embedding new ideas).

Emergency frames may contribute to reshaping dominant discourses (for example, business as usual), but this is not guaranteed. For emergency-as-reaction, such frames may fail to reshape existing discourse if they simply focus on returning to normal (see the Australian and Indian cases in Table 1). In contrast, emergency-as-strategy seeks to disrupt discursive stability, although it also contends with open-ended issues that lack a clear beginning or end and may not fit typical public understandings of an emergency. For example, 'crisification' of climate change may have been a key factor influencing discourse informing the Paris Agreement ${ }^{88}$. But policy scholars have long observed that public attention is ephemeral ${ }^{89}$, and argued that emergency involves struggle over meaning ${ }^{90}$. Thus, emergency frames may require ongoing political work to sustain discursive effects. Whether this will occur for current claims about climate and biodiversity emergencies is unclear because discourse change takes time.

Emergency frames can also introduce new imaginaries. These are (largely subconscious) images of the past or future imbued with meaning, narrative and norms about a community ${ }^{91}$, which make sense of changes beyond immediate experience ${ }^{92,93}$. Emergency-as-strategy has been criticized for reflecting technocratic ${ }^{53,54}$ and even apocalyp$\mathrm{tic}^{94}$ imaginaries, which fail to generate alternative ideas about the future. The language "depicts the future to be both utterly uncertain and yet eschatological...[where] The next catastrophe is certain, but until it will have happened one cannot predict anything about

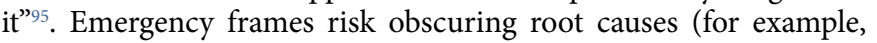
capitalism, viewing nature as an inexhaustible resource) through imaginaries involving rapid solutions that perpetuate the status quo, potentially fostering a depoliticized discourse that is void of imagination ${ }^{79,96}$. Yet, emergency can also invoke imaginaries that break with the past and create hope for the future ${ }^{43,97}$.

A key question is whether emergency frames usefully embed new ideas in prevailing discourse. For example, emergency-as-strategy could instil greater imperative for climate action in sluggish political systems, or open up new rhetorical strategies to avoid the easy dismissal of climate action ${ }^{98,99}$. But it could also prematurely close down discursive space in the search for concrete solutions ${ }^{94}$, and even trigger counterdiscourses (for example, charges of alarmism or reactionary conservatism) that stall action and reinforce polarization. Whether emergency is accommodated in sustainability discourse may, therefore, rest on the creation and acceptance of new notions of emergency that go beyond technocratic management and embrace normative directionality about the future. For example, the notion of a 'long emergency' ${ }^{100}$ provides impetus for such an approach. This might also be an important step towards governance in the Anthropocene where deep time horizons become a key concern ${ }^{101}$.

Impacts on institutions. Institutions refer to "rights, rules, and decision-making procedures that gives rise to a social practice, assign roles to the participants... and guide interactions among occupants of these roles"102. Thus, institutions stabilize social expectations and provide frameworks within which complex social and political activity becomes possible. While institutions are both formal and informal, we focus on the more readily observable formal aspects. Emergency frames may work within existing institutions (for example, constitutions, resource governance arrangements) or seek to disrupt them (for example, calls for extraordinary action or new mechanisms of steering action), raising questions about the consequences for existing institutions (for example, strengthening, weakening).

Emergency frames could strengthen policy portfolios core to state sovereignty, such as essential services, homeland security, intelligence, military and finance, but perhaps also others linked to a particular emergency (for example, health, infrastructure). Military involvement is now used in situations of emergency-as-reaction to extreme climate impacts (for example, hurricanes, floods, fires), which may increase as climate change threatens national security $^{83,103}$. While proponents of climate and/or biodiversity emergency frames may hope that emergencies elevate sustainability 


\section{Box 3 | Climate emergency declarations by governments and} civil society

Responding to campaigns of environmental movements, the city of Darebin (Australia) became the first local government in the world to declare a climate emergency in 2016. Other local governments emulated the move throughout 2017. In 2018, the trend gained momentum through the release of the IPCC's Special Report on Global Warming of $1.5^{\circ} \mathrm{C}$ and the first wave of school student strikes for climate action (Fridays For Future). By 2019, over 1,500 climate emergency declarations had been adopted by governments and jurisdictions in 29 countries. The majority were issued by local governments, mostly in English-speaking countries in the Global North.

Climate emergency declarations reflect a logic of emergency-as-strategy, but sometimes invoke experienced or expected impacts (for example, the declaration by the Maldives in response to existential threat). Yet, the effects so far are less spectacular than activists had imagined. They appear to have increased awareness and potentially increased belief in political activism $^{60}$ (engagement). School strikes have strengthened the voice and moral authority of young people, evidenced through Greta Thunberg speaking at major political gatherings (for example, the United Nations Framework Convention on Climate Change, Davos). The long-term effects remain unclear, but the rise of the youth movement has changed the political landscape and discourse (empowerment), possibly weakening the voice of climate sceptics (disempowerment). The declarations imply action within existing rules (for example, policy-making processes, constitutions) and, so far, do not show evidence of authoritarian politics. In many cases, they emerged from negotiations between grassroots movements, elected officials and even individuals ${ }^{85}$ (political authority). Climate emergency declarations strongly reinforce science-based, pro-action discourses (discourses). Yet, in municipalities and national governments, they point to incremental rather than transformative action agendas ${ }^{85}$. They appear to reiterate previous policy positions (institutions). Very few declarations have been accompanied by new steering mechanisms (for example, plans and targets, participatory procedures, new administrative bodies) and allocation of resources $^{85}$. However, the declarations may build solidarity at multiple levels of governance and demonstrate the possibilities of collaboration. There may also be indirect effects, such as the Fridays For Future movement increasing the ambition of the European Green Deal, although further assessments are needed to establish causal links between advocacy and ambition.

policy portfolios, it seems equally likely that these will be subordinated to areas critical to state security. At an international level, emergency frames could strengthen institutional arrangements around specific issues. For example, biodiversity emergency could strengthen the fragmented global assemblage of assessments, treaties and agreements. Climate emergency could accelerate the formation of new assemblages around geoengineering particularly through re-appropriating demands for urgent action ${ }^{86,104}$.

Emergency frames may precipitate new mechanisms of steering action. For example, disaster/crisis scholars observe that 'focusing events $^{105}$ (such as disasters ${ }^{106}$ ) may generate new frames that drive policy change. Public inquiries following disasters/crises may also lead to policy or legislative change. For open-ended emergencies (for example, climate, biodiversity) this is less clear. Institutional effects may depend on pre-existing capacities, such as the capacity to learn from experience and public inquiries ${ }^{107}$ and anticipate future problems. Municipalities declaring climate emergency may establish new mechanisms to influence planning and infrastructure decisions, such as citizens' assemblies ${ }^{85}$. Yet, hopeful expectations should be tempered by the typically slow nature of institutional change due to path dependencies, inefficient adaptation to new circumstances, 'lock-in' of institutions with technologies and behaviours, and ephemeral opportunities for deliberate change ${ }^{108}$.

\section{Implications and next steps}

It is clear that emergency frames can have diverse effects in sustainability science and politics. It also seems likely that the use of emergency frames will persist, given growing disruption of the Earth system and public demand for ambitious action on issues such as climate change and biodiversity. This Review provides a foundation for future work to systematically examine the political effects of emergency frames, and builds a shared vocabulary for comparative analysis.

The question of whether emergency frames enhance or reduce prospects for mobilizing ambitious action defies straightforward answer. Evidence is ambiguous and sometimes conflicting, and different combinations of effects may occur in different contexts. Our illustrative cases (Table 1 and Boxes 1-3) provide at best limited evidence that emergency frames lead to new forms of ambitious and/or transformative action in the short term. Although this does not mean that indirect or longer-term effects (for example, enduring shifts in discourse or institutional change) will not occur. Over time, emergency frames could generate new discourses that draw attention to irreversible consequences of inaction and existential imperatives for action, or at least increase public awareness. Yet, emergency frames could legitimate new repertoires of action not intended by proponents, such as geoengineering ${ }^{86,109,110}$. Deployment of emergency frames also risks triggering exclusionary responses due to prioritization of urgency over deliberation. Current literature shows concerns over technocratic forms of knowledge and decision-making that run counter to calls to pluralize knowledge and action in response to diverse social, ecological and political concerns $s^{53}$. Long-term mobilization for issues such as climate change and biodiversity loss (for example, 'long emergencies $^{100}$ ) begs the question of how long emergency frames can be credibly and meaningfully sustained.

A key next step is to look in depth within specific bodies of literature (for example, disciplines covered here, as well as particular fields such as disaster/crisis management and securitization) to draw out further conceptual and comparative insights. In doing so, it will be important to return to a broad view of multiple political effects as highlighted in Fig. 1. Another next step is to systematically review each of the five dimensions of the typology. Current evidence is diverse, patchy and sometimes contradictory. Our focus here has been on an interdisciplinary synthesis of evidence to identify points of agreement/disagreement and map the overall contours of the problem. Systematic evidence assessment within each effect dimension would be a valuable next step to generate hypotheses and identify scope conditions that can help to disentangle this complex picture.

Emergency frames are both an empirical claim about the world and a political intervention. As a strategy for generating collective action, this approach is complicated by existing ideas and practices connected to the notion of emergency, even though declarations of emergency by non-state actors may seek a new type of emergency politics that foregrounds ethical concerns. Commonly, emergency frames initiated by governments have an uncomfortable relationship with governing practices that have historically been used to exercise transgression of liberties, and even violence and oppression. Newer emergency frames advocated by civil society have come to be seen as a tool of political struggle towards sustainability and justice. Scholars frequently view government-initiated emergency with caution or even cynicism, but emergencies called by civil society challenge us to think about emergency in a new light, potentially 
Box 4 | Practical implications of emergency frames for sustainability governance

(1) Emergency frames do not necessarily overcome the challenges of stimulating ambitious action in the near term, but they may have an important role in longer-term political struggles over sustainability issues. If near-term action is the goal, then other strategies may be more effective that are less at risk of pushback, polarization and unintended consequences. Paradoxically, emergency frames may enable more radical changes in the future due to enduring changes in discourse.

(2) Whether emergency frames 'should' be a part of sustainability science and policy is an open question, which to some extent depends on underlying views about the role of process versus outcome in sustainability governance. Those who value a process-focused approach may be put off by emergency frames regardless of how they are mobilized and emphasize adverse consequences. Yet, those focused on climate outcomes may be more comfortable with emergency frames despite the risk of adverse consequences, viewing this as a necessary political concession.

(3) Increasing occurrences of emergency-as-reaction (for example, floods, droughts, wildfires) in coming years may reinforce the legitimacy of emergency-as-strategy due to upheaval. Increasing experiences of emergency-as-reaction and increasing deployment of emergency-as-strategy (for example, new types or bundles of emergency), may lead to broad-based legitimacy for deliberate radical changes in society. However, risks are likely to remain.

(4) Ethical concerns (for example, equity, justice) must remain at the heart of emergency frames, both to stave off misuses (for example, power grabs, erosion of rights) and to proactively address concerns of those who may be wary of emergency frames. This is especially important for emergency-as-strategy, which is forward-looking and essentially seeks to stimulate a critical juncture, which may open up moments of co-optation risk.

(5) Accounting for the complex effects of emergency frames requires attention to context. The five dimensions identified in this Review are closely tied to specific contexts (for example, social, political, geographical, historical), suggesting that context has a key mediating role in understanding the effects of emergency frames. A research agenda on the comparative study of emergency frames and their effects in sustainability across contexts and policy domains is needed. The typology in this Review provides a foundation for such endeavour.

even re-theorizing the very notion as a potential tool of emancipation within a longer-term perspective of societal transformations.

Scholars, policymakers and civil society should not be too quick to embrace nor discard emergency frames, as they may have different implications depending on time frame and context (Box 4). Some contexts may be able to absorb the risk of adverse consequences (for example, robust democracies), whereas others may be less well placed to do $\mathrm{so}^{48}$ (for example, those with authoritarian tendencies or strong political polarization). In the strategic deployment of emergency frames, there is a delicate balance between maintaining discomfort, but not overwhelming people and decision-makers. Such productive friction probably requires balancing critical calls for radical change with concrete (even if imperfect) actions, and positive or hopeful messages side by side. This balance will of course be challenging to navigate, will differ across societies and will continuously evolve. Within this mix, emergency frames may have a key, but probably only partial, role to play-relying entirely on emergency frames to motivate collective sustainability action may risk seizing up the gears of society and politics rather than lubricating them.

Received: 30 October 2020; Accepted: 22 June 2021; Published online: 26 July 2021

\section{References}

1. Tickner, D. et al. Bending the curve of global freshwater biodiversity loss: an emergency recovery plan. BioScience 70, 330-342 (2020).

2. Wilson, A. J. \& Orlove, B. What do We Mean When We Say Climate Change is Urgent? (Earth Institute, Columbia Univ., 2019).

This paper reflects on the notion of 'urgency' in climate change debates, finding that it acts as a boundary object between science, policy, civil society and media, but can also trigger a range of psychological effects.

3. Grant, M. J. \& Booth, A. A typology of reviews: an analysis of 14 review types and associated methodologies. Health Info. Libr. J. 26, 91-108 (2009).

4. Enqvist, J. P. \& Ziervogel, G. Water governance and justice in Cape Town: an overview. WIREs Water 6, e1354 (2019).

5. Australian Government Royal Commission into National Natural Disaster Arrangements Report (Commonwealth of Australia, 2020).

6. Ripple, W. J., Wolf, C., Newsome, T. M., Barnard, P. \& Moomaw, W. R. World scientists' warning of a climate emergency. BioScience 70, 8-12 (2019) This paper asserts that the world is facing a climate emergency, drawing on macro trends across a variety of Earth system processes, arguing that scientists have a moral obligation to bring this to public attention, and is signed by over 11,000 scientists.

7. Spratt, D. \& Sutton, P. Climate Code Red: The Case for Emergency Action (Scribe Publications, 2008).

8. Solomon, C. G. \& LaRocque, R. C. Climate change-a health emergency. N. Engl. J. Med. 380, 209-211 (2019).

9. Gilding, P. Why I welcome a climate emergency. Nature 573, 311 (2019).

10. Holmberg, A. \& Alvinius, A. Children's protest in relation to the climate emergency: a qualitative study on a new form of resistance promoting political and social change. Childhood 27, 78-92 (2020).

11. Skrimshire, S. Activism for end times: millenarian belief in an age of climate emergency. Polit. Theol. 20, 518-536 (2019).

12. Thackeray, S. J. et al. Civil disobedience movements such as school strike for the climate are raising public awareness of the climate change emergency. Glob. Change Biol. 26, 1042-1044 (2020).

13. Cohen, D. A. Confronting the urban climate emergency: critical urban studies in the age of a green new deal. City 24, 52-64 (2020).

14. Davidson, $K$. et al. The making of a climate emergency response: examining the attributes of climate emergency plans. Urban Clim. 33, 100666 (2020).

15. Chou, M. Australian local governments and climate emergency declarations: reviewing local government practice. Aust. J. Publ. Adm. https://doi.org/10.1111/1467-8500.12451 (2020).

16. Roe, D. Biodiversity loss-more than an environmental emergency. Lancet Planet. Health 3, e287-e289 (2019).

17. Making Peace with Nature: A Scientific Blueprint to Tackle the Climate, Biodiversity and Pollution Emergencies (United Nations Environment Programme, 2021).

18. The Peoples' Climate Vote (United Nations Development Programme \& Univ. Oxford, 2021)

19. Maerz, S. F., Lührmann, A., Lachapelle, J. \& Edgell, A. B. Worth the Sacrifice? Illiberal and Authoritarian Practices During COVID-19 (The Varieties of Democracy Institute, Univ. Gothenburg, 2020).

20. Manzanedo, R. D. \& Manning, P. COVID-19: lessons for the climate change emergency. Sci. Total Environ. 742, 140563 (2020).

21. 't Hart, P., Tindall, K. \& Brown, C. Crisis leadership of the Bush presidency: advisory capacity and presidential performance in the acute stages of the 9/11 and Katrina crises. Pres. Stud. Q. 39, 473-493 (2009).

22. Boin, A., 't Hart, P. \& McConnell, A. Crisis exploitation: political and policy impacts of framing contests. J. Eur. Public Policy 16, 81-106 (2009).

23. Tierney, K., Bevc, C. \& Kuligowski, E. Metaphors matter: disaster myths, media frames, and their consequences in Hurricane Katrina. Ann. Am. Acad. Polit. Soc. Sci. 604, 57-81 (2006).

24. Lizarralde, G., Johnson, C. \& Davidson, C. Rebuilding after Disasters: From Emergency to Sustainability (Routledge, 2010).

25. Armitage, J. State of emergency: an introduction. Theory Cult. Soc. 19, 27-38 (2002).

26. Scarry, E. Thinking in an Emergency (WW Norton, 2012).

27. Lindley, A. Crisis and Migration: Critical Perspectives (Routledge, 2014).

28. Hussain, N. The Jurisprudence of Emergency: Colonialism and the Rule of Law (Univ. Michigan Press, 2019). 
29. Neocleous, M. The problem with normality: taking exception to "permanent emergency". Alternatives 31, 191-213 (2006).

This paper provides a historical overview of the deployment of emergency declarations by governments as a tool for political oppression.

30. Goffman, E. Frame Analysis: An Essay on the Organisation of Experience (Northeastern Univ. Press, 1986).

31. van Hulst, M. \& Yanow, D. From policy "frames" to "framing": theorizing a more dynamic, political approach. Am. Rev. Public Adm. 46, 92-112 (2016)

32. Borah, $\mathrm{P}$. Conceptual issues in framing theory: a systematic examination of a decade's literature. J. Commun. 61, 246-263 (2011).

33. Rein, M. \& Schön, D. Frame-critical policy analysis and frame-reflective policy practice. Knowl. Policy 9, 85-104 (1996).

34. Schön, D. A. \& Rein, M. Frame Reflection: Toward the Resolution of Intractable Policy Controversies (Basic Books, 1994).

35. Chong, D. \& Druckman, J. N. Framing theory. Annu. Rev. Polit. Sci. 10, 103-126 (2007).

36. Slothuus, R. \& de Vreese, C. H. Political parties, motivated reasoning, and issue framing effects. J. Polit. 72, 630-645 (2010).

37. Wiest, S. L., Raymond, L. \& Clawson, R. A. Framing, partisan predispositions, and public opinion on climate change. Glob. Environ. Change 31, 187-198 (2015).

38. Nisbet, M. C. Communicating climate change: why frames matter for public engagement. Environ. Sci. Policy Sustain. Dev. 51, 12-23 (2009).

39. Hodder, P. \& Martin, B. Climate crisis? The politics of emergency framing Econ. Polit. Wkly 44, 53-60 (2009).

40. Boin, A., McConnell, A. \& 't Hart, P. Governing after Crisis: The Politics of Investigation, Accountability and Learning (Cambridge Univ. Press, 2008).

41. Brändström, A. \& Kuipers, S. From 'normal incidents' to political crises: understanding the selective politicization of policy failures. Gov. Oppos. 38, 279-305 (2003).

42. Hood, C. The Blame Game: Spin, Bureaucracy, and Self-preservation in Government (Princeton Univ. Press, 2011).

43. Anderson, B. Emergency futures: exception, urgency, interval, hope. Sociol. Rev. 65, 463-477 (2017).

This paper discusses how emergency declarations can function astions of hope, as they can allow conditions in the present to be recognized as emergencies while envisioning a future that is 'other' than the present.

44. Mori, A. S. Advancing nature-based approaches to address the biodiversity and climate emergency. Ecol. Lett. 23, 1729-1732 (2020).

45. Hanna, L. Climate change: past and projected threats to food and water security $=$ public health emergency. Eur. J. Public Health 30, ckaa165.010 (2020).

46. Mapp, S. \& Gatenio Gabel, S. The climate crisis is a human rights emergency. J. Hum. Rights Soc. Work 4, 227-228 (2019).

47. Tuana, N. Climate apartheid: the forgetting of race in the Anthropocene. Crit. Philos. Race 7, 1 (2019).

48. Greitens, S. C. Surveillance, security, and liberal democracy in the post-COVID world. Int. Organ. 74, E169-E190 (2020).

49. Thomson, S. \& Ip, E. C. COVID-19 emergency measures and the impending authoritarian pandemic. J. Law Biosci. 7, lsaa064 (2020)

50. Boin, A., Stern, E. \& Sundelius, B. The Politics of Crisis Management: Public Leadership Under Pressure (Cambridge Univ. Press, 2016).

51. Van Buuren, A., Vink, M. \& Warner, J. Constructing authoritative answers to a latent crisis? Strategies of puzzling, powering and framing in Dutch climate adaptation practices compared. J. Comp. Policy Anal. 18, 70-87 (2016)

52. Brinks, V. \& Ibert, O. From corona virus to corona crisis: the value of an analytical and geographical understanding of crisis. Tijdschr. Econ. Soc. Geogr. 111, 275-287 (2020).

53. Hulme, M. Climate emergency politics is dangerous. Issues Sci. Technol. 36, 23-25 (2019)

This paper argues that climate emergency frames the narrow scope of sustainability concerns, which leads to technocratic responses and undermines the possibility for including plural perspectives in shaping action towards sustainability.

54. Hulme, M., Lidskog, R., White, J. M. \& Standring, A. Social scientific knowledge in times of crisis: what climate change can learn from coronavirus (and vice versa). WIREs Clim. Change 11, e656 (2020).

55. Funtowicz, S. From risk calculations to narratives of danger. Clim. Risk Manag. 27, 100212 (2020).

56. Communication from the Commission to the European Parliament, the European Council, the Council, the European Economic and Social Committee and the Committee of the Regions: The European Green Deal (European Commission, 2019).

57. Ocasio-Cortez, A. House Resolution 109-116th Congress (2019-2020): Green New Deal Resolution-Recognizing the duty of the Federal Government to Create a Green New Deal (United States Congress, 2019).

58. Pelling, M. Adaptation to Climate Change: From Resilience to Transformation (Routledge, 2011).
59. Klein, N. The Shock Doctrine: The Rise of Disaster Capitalism (Knopf Canada, 2007)

60. Sabherwal, A. et al. The Greta Thunberg effect: familiarity with Greta Thunberg predicts intentions to engage in climate activism in the United States. J. Appl. Soc. Psychol. 51, 321-333 (2021).

61. Kleres, J. \& Wettergren, A. Fear, hope, anger, and guilt in climate activism. Soc. Mov. Stud. 16, 507-519 (2017)

This paper explores the emotions of youth climate activists, finding that these actors develop strategies to manage complex combinations of negative and positive emotions, giving rich insights from in-depth qualitative investigation.

62. Goodwin, J., Jasper, J. M. \& Polletta, F. in The Blackwell Companion to Social Movements (eds Snow, D. A. et al.) 413-432 (Blackwell, 2007).

63. Ruiter, R. A. C., Abraham, C. \& Kok, G. Scary warnings and rational precautions: a review of the psychology of fear appeals. Psychol. Health 16, 613-630 (2001).

64. O’Neill, S. \& Nicholson-Cole, S. "Fear won't do it": promoting positive engagement with climate change through visual and iconic representations. Sci. Commun. 30, 355-379 (2009).

65. Pyszczynski, T., Lockett, M., Greenberg, J. \& Solomon, S. Terror management theory and the COVID-19 pandemic. J. Humanist. Psychol. 61, 173-189 (2021).

66. Wolfe, S. E. \& Tubi, A. Terror management theory and mortality awareness: a missing link in climate response studies? WIREs Clim. Change 10 e566 (2019).

67. Hornsey, M. J. \& Fielding, K. S. Understanding (and reducing) inaction on climate change. Soc. Issues Policy Rev. 14, 3-35 (2020).

68. Weick, K. E. Small wins: redefining the scale of social problems. Am. Psychol. 39, 40-49 (1984).

69. Sharot, T. The optimism bias. Curr. Biol. 21, R941-R945 (2011)

70. Madan, C. R., Spetch, M. L. \& Ludvig, E. A. Rapid makes risky: time pressure increases risk seeking in decisions from experience. J. Cogn. Psychol. 27, 921-928 (2015).

71. Michie, S., West, R. \& Harvey, N. The concept of "fatigue" in tackling COVID-19. Br. Med. J. 371, m4171 (2020).

72. Methmann, C. \& Rothe, D. Politics for the day after tomorrow: the logic of apocalypse in global climate politics. Secur. Dialogue 43, 323-344 (2012).

73. Moser, S. C. \& Dilling, L. Making climate HOT. Environ. Sci. Policy Sustain Dev. 46, 32-46 (2004)

74. Lowe, $\mathrm{T}$. et al. Does tomorrow ever come? Disaster narrative and public perceptions of climate change. Public Underst. Sci. 15, 435-457 (2006).

75. Byrne, S. \& Hart, P. S. The boomerang effect: a synthesis of findings and a preliminary theoretical framework. Ann. Int. Commun. Assoc. 33 3-37 (2009).

76. Hung, L.-S. \& Bayrak, M. M. Comparing the effects of climate change labelling on reactions of the Taiwanese public. Nat. Commun. 11, 6052 (2020).

77. Partzsch, L. 'Power with' and 'power to' in environmental politics and the transition to sustainability. Environ. Polit. 26, 193-211 (2017).

78. Feldman, H. R. A rhetorical perspective on youth environmental activism. J. Sci. Commun. 19, C07 (2020).

79. Anson, A. Master metaphor: environmental apocalypse and settler states of emergency. Resil. J. Environ. Hum. 8, 60-81 (2021).

80. Pupavac, V. The politics of emergency and the demise of the developing state: problems for humanitarian advocacy. Dev. Pract. 16, 255-269 (2006).

81. McDonald, M. After the fires? Climate change and security in Australia. Aust. J. Polit. Sci. 56, 1-18 (2020).

82. Buzan, B., Wæver, O. \& de Wilde, J. Security: A New Framework for Analysis (Lynne Rienner, 1998)

83. Oels, A in Climate Change, Human Security and Violent Conflict (eds Scheffran, J. et al) 185-205 (Springer, 2012).

84. Trihartono, A., Viartasiwi, N. \& Nisya, C. The giant step of tiny toes: youth impact on the securitization of climate change. IOP Conf. Ser. Earth Environ. Sci. 485, 012007 (2020).

85. Ruiz Campillo, X., Castan Broto, V. \& Westman, L. Motivations and intended outcomes in local governments' declarations of climate emergency. Polit. Gov. 9, 17-28 (2021)

86. Markusson, N., Ginn, F., Singh Ghaleigh, N. \& Scott, V. 'In case of emergency press here’ framing geoengineering as a response to dangerous climate change. WIREs Clim. Change 5, 281-290 (2014). Using the example of geoengineering, this paper argues that emergency frames can provide pre-emptive justification for certain solutions and foreclose deliberations in environmental governance.

87. Hajer, M. A. The Politics of Environmental Discourse: Ecological Modernization and the Policy Process (Oxford Univ. Press, 1995).

88. Paglia, E. The socio-scientific construction of global climate crisis Geopolitics 23, 96-123 (2018).

89. Weible, C. M. \& Sabatier, P. A. Theories of the Policy Process (Westview, 2017). 
90. 't Hart, P. \& Tindall, K. Framing the Global Economic Downturn: Crisis Rhetoric and the Politics of Recessions (ANU E Press, 2009).

91. Diehl, P. Temporality and the political imaginary in the dynamics of political representation. Soc. Epistemol. 33, 410-421 (2019).

92. Milkoreit, M. in Reimagining Climate Change (eds Wapner, P. \& Elvar, H.) 171-191 (Routledge, 2016)

93. Norgaard, K. M. The sociological imagination in a time of climate change. Glob. Planet. Change 163, 171-176 (2018).

94. Swyngedouw, E. Apocalypse forever? Theor. Cult. Soc. 27, 213-232 (2010)

95. Opitz, S. \& Tellmann, U. Future emergencies: temporal politics in law and economy. Theor. Cult. Soc. 32, 107-129 (2015).

96. Schinkel, W. The image of crisis: Walter Benjamin and the interpretation of 'crisis' in modernity. Thesis Eleven 127, 36-51 (2015).

97. Slaughter, R. A. Sense making, futures work and the global emergency. Foresight 14, 418-431 (2012).

98. Wilkinson, C. \& Clement, S. Geographers declare (a climate emergency)? Aust. Geogr. 52, 1-18 (2021).

99. Spoel, P., Goforth, D., Cheu, H. \& Pearson, D. Public communication of climate change science: engaging citizens through apocalyptic narrative explanation. Tech. Commun. Q. 18, 49-81 (2008)

100. Orr, D. W. Dangerous Years: Climate Change, the Long Emergency, and the Way Forward (Yale Univ. Press, 2016).

101. Biermann, F. The Anthropocene: a governance perspective. Anthr. Rev. 1, 57-61 (2014)

102. Young, O. R., King, L. A. \& Schroeder, H. Institutions and Environmental Change: Principal Findings, Applications, and Research Frontiers (MIT, 2008)

103. McDonald, M. Discourses of climate security. Polit. Geogr. 33 42-51 (2013)

104. Asayama, S., Bellamy, R., Geden, O., Pearce, W. \& Hulme, M. Why setting a climate deadline is dangerous. Nat. Clim. Change 9, 570-572 (2019).

105. Kingdon, J. W. Agendas, Alternatives, and Public Policies (Pearson Education, 2014).

106. Birkland, T. A. Lessons of Disaster: Policy Change After Catastrophic Events (Georgetown Univ. Press, 2006).

107. Eburn, M. \& Dovers, S. Learning lessons from disasters: alternatives to royal commissions and other quasi-judicial inquiries. Aust. J. Publ. Admin. 74, 495-508 (2015)

108. Patterson, J. J. Remaking Political Institutions: Climate Change and Beyond (Cambridge Univ. Press, 2021).

109. Sillmann, J. et al. Climate emergencies do not justify engineering the climate. Nat. Clim. Change 5, 290-292 (2015).

110. Horton, J. B. The emergency framing of solar geoengineering: time for a different approach. Anthr. Rev. 2, 147-151 (2015).

111. van Oldenborgh, G. J. et al. Attribution of the Australian bushfire risk to anthropogenic climate change. Nat. Hazards Earth Syst. Sci. 21, 941-960 (2021).

112. Lockie, S. Sociological responses to the bushfire and climate crises. Environ Soc. 6, 1-5 (2020)

113. Dash, P. \& Punia, M. Governance and disaster: analysis of land use policy with reference to Uttarakhand flood 2013, India. Int. J. Disaster Risk Reduct. 36, 101090 (2019).
114. Wilshusen, P. R., Brechin, S. R., Fortwangler, C. L. \& West, P. C. Reinventing a square wheel: critique of a resurgent 'protection paradigm' in international biodiversity conservation. Soc. Natur. Resour. 15, 17-40 (2002).

115. Yu, P., Xu, R., Abramson, M. J., Li, S. \& Guo, Y. Bushfires in Australia: a serious health emergency under climate change. Lancet Planet. Health 4, e7-e8 (2020).

116. Hunt, K. M. R. \& Menon, A. The 2018 Kerala floods: a climate change perspective. Clim. Dynam. 54, 2433-2446 (2020)

117. Ahmadi, M. S., Sušnik, J., Veerbeek, W. \& Zevenbergen, C. Towards a global day zero? Assessment of current and future water supply and demand in 12 rapidly developing megacities. Sustain. Cities Soc. 61, 102295 (2020).

118. Padma, T. V. Mining and dams exacerbated devastating Kerala floods. Nature 561, 13-14 (2018).

119. Joseph, J. K. et al. Community resilience mechanism in an unexpected extreme weather event: an analysis of the Kerala floods of 2018, India. Int J. Disaster Risk Reduct. 49, 101741 (2020).

\section{Acknowledgements}

We acknowledge all participants of the Innovative Session: 'Helping or hindering? The political effects of 'emergency' frames in environmental governance', held at the 2020 Virtual Forum on Earth System Governance. J.P. received funding from the European Research Council as principal investigator of the project BACKLASH (grant agreement number 949332). C.W. received funding from the Australian Research Council as principal investigator of the project Foresight in Times of Disruption (grant agreement noumber DE200100922). L.W. received funding from the European Research Council as a member of the project LO-ACT (grant agreement number 804051).

\section{Author contributions}

All authors (J.P., C.W., L.W., M.C.B., M.M. and D.J.) contributed to conception and design of the work, analysis and interpretation of data, and writing of the manuscript text.

\section{Competing interests}

The authors declare no competing interests.

\section{Additional information}

Supplementary information The online version contains supplementary material available at https://doi.org/10.1038/s41893-021-00749-9.

Correspondence should be addressed to J.P.

Peer review information Nature Sustainability thanks Edward Maibach and the other, anonymous, reviewer(s) for their contribution to the peer review of this work.

Reprints and permissions information is available at www.nature.com/reprints.

Publisher's note Springer Nature remains neutral with regard to jurisdictional claims in published maps and institutional affiliations.

(c) Springer Nature Limited 2021 